\title{
Immunoglobulin subclass in experimental murine Toxocara cati infection
}

\author{
Kusnoto ${ }^{1}$, Setiawan Koesdarto ${ }^{1}$, Sri Mumpuni ${ }^{1}$ and R. Heru Prasetyo ${ }^{2}$
}

1. Department of Parasitology, Faculty of Veterinary Medicine, Universitas Airlangga, Surabaya, East Java, Indonesia; 2. Department of Parasitology, Faculty of Medicine, Universitas Airlangga, Surabaya, East Java, Indonesia. Corresponding author: R. Heru Prasetyo, e-mail: rheru_prasetyo@yahoo.co.id

Co-authors: Kusnoto: kk.kusnoto@yahoo.com, SK: skoesdarto@yahoo.com, SM: mumpuni-s@yahoo.com Received: 20-06-2017, Accepted: 23-10-2017, Published online: 13-11-2017

doi: 10.14202/vetworld.2017.1333-1336 How to cite this article: Kusnoto, Koesdarto S, Mumpuni S, Prasetyo RH (2017) Immunoglobulin subclass in experimental murine Toxocara cati infection, Veterinary World, 10(11): 1333-1336.

\begin{abstract}
Aim: The aim of this study was to detect specific immunoglobulin (Ig) that could be used to determine monoclonal antibody in conjugate-making an effort for the indirect enzyme-linked immunosorbent assay (ELISA) diagnostic kit of toxocariasis in human.

Materials and Methods: The study was conducted to assess the Ig profile, based on ELISA-isotyping, in mice infected with second stage larvae eggs of Toxocara cati. The optical density values of anti-T. cati mice serum IgG subclasses were analyzed by applying ANOVA factorial.
\end{abstract}

Results: The specific IgG subclass in mice infected with T. cati mice was found to be IgG2 $\beta$.

Conclusion: Subclass of $\mathrm{IgG}$, especially $\operatorname{IgG} 2 \beta$, can provide leads about the use of the monoclonal antibody in conjugate making an effort for the indirect ELISA diagnostic kit.

Keywords: diagnostic kit, enzyme-linked immunosorbent assay, human, immunoglobulin G subclass, monoclonal antibody, toxocariasis, Toxocara cati.

\section{Introduction}

The disease caused by Toxocara cati infection in humans is a helminth zoonosis, which is mostly found in children $[1,2]$. However, there were some cases recorded in adults also [3]. Toxocariasis, caused by $T$. cati needs more attention due to the high population of cats in Indonesia and the close association of these pets to humans. The habit of a cat to hide its feces after defecation may prolong the survivability of worm eggs in the soil [4]. Furthermore, we should also be aware of a high prevalence of toxocariasis in Surabaya. It was reported that the prevalence of toxocariasis in stray cats was about $60.9 \%$ of 69 samples [5]. About $31.9 \%$ of soil around slaughterhouses and about $20.6 \%$ of the soil around dairy farms were reported to contain eggs of Toxocara spp. included T. cati [6]. This situation could increase the risk of toxocariasis [7]. This finding supports the fact that human toxocariasis from infective eggs, containing second-stage (L2) larvae [8]. These infections were called human toxocariasis, referring to one of most common helminth zoonosis [9]. Human toxocariasis was the most prominent of all nematode diseases because it caused major health problems in children

Copyright: Kusnoto, et al. Open Access. This article is distributed under the terms of the Creative Commons Attribution 4.0 International License (http://creativecommons.org/licenses/ by/4.0/), which permits unrestricted use, distribution, and reproduction in any medium, provided you give appropriate credit to the original author(s) and the source, provide a link to the Creative Commons license, and indicate if changes were made. The Creative Commons Public Domain Dedication waiver (http:// creativecommons.org/publicdomain/zero/1.0/) applies to the data made available in this article, unless otherwise stated. and ocular destruction on adults. Human toxocariasis has been classified into two categories, visceral toxocariasis and ocular toxocariasis due to visceral larvae migrans and ocular larvae migrans [10]. These had been global concern that $T$. cati, including visceral and ocular larvae migrans as their clinical manifestations were the main source of infections in human [11]. Considering the fatality due to ocular or cerebral larvae migrans, immunodiagnosis in human should be conducted. The presence of larvae in body tissues would trigger immune responses marked by $\operatorname{IgE}$ and an increase in the count of eosinophils leading to a specific type of antibody-dependent cell mediated cytotoxicity [12].

Immunological diagnosis of human toxocariasis conducted through suspected blood serum examination required high sensitivity and specificity. Enzymelinked immunosorbent assay (ELISA) technique is reliable for its high sensitivity. In indirect ELISA technique, in addition to needing T. cati antigens and suspect animal serum containing polyclonal antibody, it also requires enzyme-labeled monoclonal antibodies (conjugate) as biomarkers [13].

The aim of this study was to detect specific immunoglobulin (Ig) that could be used to determine monoclonal antibody in conjugate-making effort for the indirect ELISA diagnostic kit of human toxocariasis.

\section{Materials and Methods}

\section{Ethical approval}

The present study was approved by Ethical Committee vide Ethical Clearance No. 285-KE Animal 
Care and Use Committee, Faculty of Veterinary Medicine, Universitas Airlangga.

\section{Research animals}

In this research, feral cats were used as source of worms which were caught from several traditional markets in Surabaya. Male mice Balb/c, 8 weeks age was used to examine humoral immune response.

\section{Collecting adult $T$. cati. and culturing worm eggs to} obtain second-stage $T$. cati larvae (L2)

The feral cats were quarantined and underwent fecal examination to find out the presence of $T$. cati eggs. The cats without toxocariasis were released, while five cats with $T$. cati were administered piperazine adipate as anthelmintic at $50 \mathrm{mg} / \mathrm{kg}$ body weight with the consideration that those cats small and thin and not causing the worm to die and observed for 1 to 3 days to obtain adult worms which were excreted in feces $[13,14]$.

T. cati worms collected from cats were placed in Erlenmeyer flasks containing warm $\left(37^{\circ} \mathrm{C}\right)$ phosphate buffered saline (PBS) (pH 7.4). About $50 \mathrm{ml}$ PBS was added to every 20 worms and incubated in a water bath at a $37^{\circ} \mathrm{C}$ temperature for $15-20 \mathrm{~min}$. PBS solution was replaced, and incubation continued for another $15 \mathrm{~min}$ to an hour. All living worms were transferred to fresh PBS solution and incubated again for $4 \mathrm{~h}$. The live worms were collected, and the residual solutions were filtered using plastic T200 filters (which equals to $25 \mu \mathrm{m}$ ). The residue contained T. cati. eggs [15-17].

The eggs were cultured in PBS medium at room temperature for 21-28 days until second-stage larvated (L2) eggs.

\section{Infection of mice with second-stage of $T$. cati lar- vated EGGS}

Six mice were infected per os by second-stage T. cati larvated eggs (L2). On the $0,7^{\text {th }}$, and $14^{\text {th }}$ days after infection, sera samples were collected to examine Ig subclasses: $\operatorname{IgG} 1, \operatorname{IgG} 2, \operatorname{IgG} 2$, and $\mathrm{IgG} 3$ by applying ELISA sub-isotyping kit technique.

T. cati antigen $(2 \mu \mathrm{g} / \mathrm{l})$ diluted with carbonate buffer $(50 \mathrm{mmol} / \mathrm{l}$ carbonate, $\mathrm{pH} 9.6)$ then adsorbed on ELISA microplate $100 \mu \mathrm{l}$ each well and incubated at $40^{\circ} \mathrm{C}$ for one night. The microplate is then blocked with a blocking buffer ( $1 \% \mathrm{BSA}, 0.02 \% \mathrm{NaN}_{3}$ in PBS) and incubated at $37^{\circ} \mathrm{C}$ for $1 \mathrm{~h}$. Then washed with a washing buffer $(0.15 \mathrm{M} \mathrm{NaCl}, 0.05 \%$ Triton X-100, $\left.0.02 \% \mathrm{NaN}_{3}\right) 3$ times. Tested antibodies were inserted into each well $(100 \mu \mathrm{l})$ and incubated at $37^{\circ} \mathrm{C}$ for $1 \mathrm{~h}$, then washed 3 times with washing buffer, followed by addition of an antisubclass of IgG (Mouse Typer Sub-Isotyping Kit, Bio-rad) diluted with blocking buffer (1:1000 dilution) of $100 \mu \mathrm{l}$ each well and incubated at $37^{\circ} \mathrm{C}$ for $1 \mathrm{~h}$. Then microplate washed again with washing buffer and added conjugate (rabbit anti-mouse IgG labeled with alkaline phosphatase enzyme) diluted with blocking buffer $(1: 1000$ dilution) $100 \mu \mathrm{l}$ each well and incubated at $37^{\circ} \mathrm{C}$ for $1 \mathrm{~h}$. The microplate was washed again with washing buffer for subtract added $100 \mu 1$ each well and incubated for 10-30 min in dark space. Recharge is then read with ELISA reader at $405 \mathrm{~nm}$ [13].

\section{Statistical analysis}

The optical density values of anti- $T$. cati mice serum IgG subclasses were analyzed by applying analysis of variance factorial.

\section{Results and Discussion}

The optical density values of anti- $T$. cati mice serum IgG subclasses observed at different time periods indicated different results $(\mathrm{p}<0.01)$. The highest optical density values $(0.384 \pm 0.199)$ were found on the $28^{\text {th }}$ day indicating a significant difference compared to other observations. The second and third highest average optical density values were found on the $7^{\text {th }}(0.279 \pm 0.099)$ and $14^{\text {th }}$ day $(0.275 \pm 0.119)$ observations. These two values were not significantly different ( $p>0.05$ ), but these values were significantly different from the 0 to $28^{\text {th }}$ day observations.

Average optical density values of anti-T. cati mice sera for Ig-G1, Ig-G2 $\alpha$, Ig-G2 $\beta$, and Ig-G3 were $0.227,0.342,0.374$, and 0.170 , respectively. These values showed a highly significant difference $(p<0.01)$ among subclass Ig. Regardless of the observation time, the result of HSD 5\% examination indicated that the highest optical density value was found in Ig-G2 3 . This value was not significantly different from Ig-G2 $\alpha$ but it was significantly different from Ig-G1 to Ig-G3.

The statistical analysis results using ANOVA factorial on optical density of anti-T. cati mice sera indicated an interaction between observation time and IgG subclasses found. Average notations and standard deviations of combined treatments were presented in Table-1. The highest optical density average values were found on Ig-G2 $\beta$ subclass on the $28^{\text {th }}$ day observation. The same results $(p>0.05)$ were found

Table-1: Optical density values of anti-T. cati mice sera of treatment groups based on time and IgG subclasses combination.

\begin{tabular}{llc}
\hline Time & IgG subclasses & Average \pm SD \\
\hline 0 day PI & Ig-G1 & $0.168^{\mathrm{ab}} \pm 0.019$ \\
& Ig-G2a & $0.232^{\mathrm{abcd}} \pm 0.046$ \\
& Ig-G2 $\beta$ & $0.190^{\mathrm{abc}} \pm 0.052$ \\
7 days PI & Ig-G3 & $0.110^{\mathrm{a}} \pm 0.013$ \\
& Ig-G1 & $0.230^{\mathrm{abcd}} \pm 0.038$ \\
& Ig-G2a & $0.314^{\mathrm{bcd}} \pm 0.053$ \\
& Ig-G2 $\beta$ & $0.365^{\mathrm{cde}} \pm 0.072$ \\
14 days PI & Ig-G3 & $0.207^{\mathrm{abc}} \pm 0.128$ \\
& Ig-G1 & $0.243^{\mathrm{abcd}} \pm 0.085$ \\
& Ig-G2a & $0.306^{\mathrm{bcd}} \pm 0.115$ \\
& Ig-G2 $\beta$ & $0.400^{\mathrm{de}} \pm 0.072$ \\
28 days PI & Ig-G3 & $0.153^{\mathrm{ab}} \pm 0.029$ \\
& Ig-G1 & $0.267^{\mathrm{abcd}} \pm 0.129$ \\
& Ig-G2a & $0.516^{\mathrm{e}} \pm 0.222$ \\
& Ig-G2 $\beta$ & $0.540^{\mathrm{e}} \pm 0.115$ \\
& Ig-G3 & $0.212^{\mathrm{abcd}} \pm 0.022$ \\
\hline
\end{tabular}

$a, b, c, d, e$ Values in the same column with different superscripts indicate significant difference at $p<0.01(n=6)$.

$T$. cati=Toxocara cati, IgG=Immunoglobulin $\mathrm{G}$, $\mathrm{SD}=$ Standard deviation 
on combined treatments of Ig-G2 $\alpha$ subclass on the $28^{\text {th }}$ day observation, Ig-G2 $\beta$ subclass on the $14^{\text {th }}$ day observation, and Ig-G2 $\alpha$ subclass on the $7^{\text {th }}$ day observation. Meanwhile, the lowest optical density average values were found on Ig-G3 subclass indicating a nonsignificant difference $(\mathrm{p}>0.05)$ with Ig-G1, Ig-G2 $\alpha$, and Ig-G2 $\beta$ subclasses on the 0 day observation and Ig-G1 and Ig-G3 subclasses on the $7^{7^{\text {th }}}$ and $14^{\text {th }}$ observation days.

Based on the observation time, the highest anti- $T$. cati mice blood sera optical density value was found on the $28^{\text {th }}$ observation day indicating a significant difference $(\mathrm{p}<0.05)$ compared to other observation times, followed by results on the $7^{\text {th }}$ and $14^{\text {th }}$ observation days. Meanwhile, the lowest optical density value was found on day 0 . When compared with other studies which use anti-Toxocara canis mice sera, the highest optical density value was also found on the $28^{\text {th }}$ observation day while the lowest one was also found on day 0 observation indicating nonsignificant difference $(\mathrm{p}>0.05)$ with the $7^{\text {th }}$ and $14^{\text {th }}$ observation days. If this finding confirmed with the other experiment using rabbit specific anti $T$. canis IgG and excretory-secretory antigen applying ELISA technique to diagnose toxocariasis, positive responses could be detected at the $20^{\text {th }}$ day after inoculation [18]. It conducted artificial infection proposed that rabbit immune response tended to increase until $60^{\text {th }}$ day and stabilized until $210^{\text {th }}$ day after inoculation. Antibody titers could be detected for the first time at $15^{\text {th }}$ day after inoculation and rapid increase was found at $28^{\text {th }}$ to $58^{\text {th }}$ day after inoculation [19].

The highest average optical density value of mice blood sera infected by L 2 of T. cati regardless observation time was found with Ig-G2 $\beta$ which indicates nonsignificant difference from Ig-G2 $\alpha(\mathrm{p}>0.05)$. The lowest optical density values were found on Ig-G1 and Ig-G3 (Table-1).

It was found out that the highest antibody response at $7^{\text {th }}$ day after infection. The second peak was found when L2 hatched and during larvae migration to visceral organs. Immune response on stimulated all Ig classes [12]. However, it seemed that IgG2 was more prominent compared to other Ig during T. cati infection. IgG2 production was stimulated by interferon-gamma secreted by CD $8^{+} \mathrm{Th} 1$ [20].

\section{Conclusion}

Based on the findings of this study, it can be concluded that the most dominant (specific) Ig subclass found on L2-T. cati infected mice blood sera was Ig-G2 $\beta$, and it can provide leads about the use of the monoclonal antibody in conjugate-making effort for the indirect ELISA diagnostic kit.

\section{Authors' Contributions}

$\mathrm{K}$ : Research coordinator, prepared antigen and antibody, and statistical analysis. SK: Method of Indirect ELISA and ELISA-Isotyping. SM:
Prepared mice, and sampling blood mice. RHP: Drafted and revised the manuscript and corresponding author. All authors read and approved the final manuscript.

\section{Acknowledgments}

The study was supported by funding from the Directorate General of Higher Education (DIKTI) 2015, The National Education Ministry, Republic of Indonesia (018/SP2H/LT/DRPM/II/2015).

\section{Competing Interests}

The authors declare that they have no competing interests.

\section{References}

1. Ligier, M.W., Gęsicka, T.W., Dryjańska, J.S., Jóźwiak, A.M. and Wieczorek, M. (2012) Analysis of the course and treatment of toxocariasis in children-a long-term observation. Parasitol. Res., 110(6): 2363-2371.

2. Carvalho, E.A. and Rocha, R.L. (2011) Toxocariasis: Visceral larva migrans in children. J. Pediatr. Rio J., 87(2): 100-110.

3. Ahn, S.J., Woo, S.J., Jin, Y., Chang, Y.S., Kim, T.W., Ahn, J., Heo, J.W., Yu, H.G., Chung, H. and Park, K.H. (2014) Clinical features and course of ocular toxocariasis in adults. PLoS Negl. Trop. Dis., 8(6): e2938.

4. Berenji, F., Pouryousef, A., Fata, A., Mahmoudi, M., Salehi, M. and Khoshnegah, J. (2016) Seroepidemiological study of toxocariasis in the owners of domestic cats and dogs in Mashhad, Northeastern Iran. Iran J. Parasitol., 11(2): 265-268.

5. Kusnoto. (2003) Molecular Characterization of Protein of Toxocara cati and Toxocara canis to Diagnostic Development of Toxocariasis, Thesis, Universitas Airlangga, Indonesian.

6. Koesdarto, S., Uga, S., Machfudz, S.S., Mumpuni, S., Kusnoto. and Puspitawati, H. (2000) Prevalence of Toxocara vitulorum in dairy cows in Surabaya, Indonesia. Jpn. J.Parasitol., 39(5): 500-502.

7. Beer, S.A., Novosil'tsev, G.I. and Mel'nikova, L.I. (1999) The role of water factor in the dissemination of Toxocara eggs and the spread of toxocariasis in a megalopolis. Abstract. Parazitologiia, 33(2): 129-135.

8. Kilpatrick, M.E. (1992) Toxocariasis. In: Tropical Medicine. $7^{\text {th }}$ ed. W.B. Saunders Company, London. p761-764.

9. Humbert, P., Niezborala, M., Salembier, R., Aubin, F., Piarroux, R., Buchet, S. and Barale, T. (2000) Skin manifestations associated with toxocariasis: A case-control study. Dermatology, 201(3): 230-234.

10. Hubner, J., Uhlikova, M. and Leissova, M. (2001) Diagnosis of the early phase of larval toxocariasis using IgG avidity. Epidemiol. Mikrobiol. Imunol., 50(2): 67-70.

11. Havasiova, R.K, Tomasovicova, O. and Dubinsky, P. (1995) Effect of various doses of infective Toxocara canis and Toxocara cati eggs on humoral response and distribution of larvae in mice. Parasitol. Res., 81(1): 13-17.

12. Dattoli, V.C., Freire, S.M., Mendonca, L.R., Santos, P.C., Meyer, R. and Alcantara, N.M. (2011) Toxocara canis infection is associated with eosinophilin and tota $\operatorname{IgE}$ in blood donors from a large Brazilian centre. Trop. Med. Int. Health, 16(4): 514-713.

13. Jin, Y., Shen, C., Huh, S., Sohn, W.M., Choi, M.H. and Hong, S.T. (2013) Serodiagnosis of toxocariasis by ELISA using crude antigen of Toxocara canis Larvae. Korean J. Parasitol., 51(4): 433-439.

14. Koga, K., Kasuya, S., Handa, Y., Keawvichit, R., Wongworapat, K., Khamboonruang, C. and Ohtomo, H. (1992) Agar plate method, a new stool examination method 
for the diagnosis of strongyloidiasis: Field applicability and sensitivity. J. Parasitol., 78(1): 155-156.

15. Rite, D. (1996) Larval Development Assay: A Product of Csiroreseach. Horizon Technology Pvt. Limited, Roseville, Australia.

16. Soulsby, E.J.L. (1989) Toxocariasis. Brit. Vet. J., 139: 471-475.

17. Abbas, A.K., Lichtman, A.H. and Pober, J.S. (2000) Cellular and Mollecular Immunology. $4^{\text {th }}$ ed. Saunders Company, Philadelphia, PA.

18. Nicholas, W.L., Stewart, A.C. and Mitchell, G.F. (1984)
Antibody responses to Toxocara canis using sera from parasite-infected mice and protection from toxocariasis by immunisation with ES antigens. Aust. J. Exp. Biol. Med. Sci., 62(5): 619-626.

19. Maizels, R.M., Tetteh, K.K.A. and Loukas, A. (2000) Toxocara canis: Gene expressed by the arrested infective larval stage of a parasitic nematode. Int. J. Parasitol., 30: 495-508.

20. Maizels, R.M. (2013) Toxocara canis: Molecular basis of immune recognition and evasion. J. Vet. Parasitol., 193(4): 365-374.

$* * * * * * * *$ 